\author{
UDC 378. 81 \\ DOI 10.33251/2522-1477-2020-7-56-60
}

MARTYNENKO Nadiia,

Postgraduate student,

Flight academy of National Aviation University

\title{
DEFININING THE CONCEPT OF INERCURTURAL INTERACTION FOR AVIATION EDUCATION
}

The purpose of this study is to analyze different types of intercultural interaction and to give classifications and typologies of intercultural interaction. The term "intercultural interaction" is disclosed as behavior (including, but not limited to, verbal and nonverbal communication) that occurs when members of different cultural groups engage in joint activity. There have been defined the terms "dialogue of cultures" "cultural diffusion" and their relation with educational processes in Higher education institutions. We have analysed different researches about intercultural interaction from culturological, psychological, anthropological, sociological and pedagogical views.

Key words: culture; interaction; intercultural interaction; problems; classification of interaction; intercultural typology, intercultural dialogue.

Introduction. The modern development of professional education in Ukraine, in the context of globalization and European integration, requires an analysis of the urgent problem of inconsistency of the increased international requirements for specialist training and the current state of higher education. It is up to the education system to identify promising ways of overcoming this discrepancy through the modernization of the national pedagogical environment and the harmonization of education standards in line with labor market demands. And one more way is to study intercultural interaction in educational process.

For many years, culture has been a safety related issue in the aviation community. Globalization of the airline industry is now a reality and is expected to continue. As airlines of different nations continue to combine operations and increase their international destinations, cultural issues will gain prominence.

Formulation of the problem. The current European perspective on common approaches to foreign language teaching shows that over time, there has been a gradual transformation of the common goals and content of learning - from language learning as a system, then as a means of general and professional-oriented communication to language-oriented learning as a means of entry into the culture of other nations. The idea of a coherent and interconnected study of language and culture at the present stage of the development of theoretical foundations is central. The ultimate goal of such training is the formation of a creative personality who, through active cognitive activity, creates her own multicultural picture of the modern world, which enables her to confidently overcome socio-cultural barriers and to interact with representatives of other linguistic and cultural societies and condition her readiness for communication. This readiness, which has emerged as a result of the synthesis of realized linguistic and cultural learning goals, is described as an intercultural communicative interaction. Its ultimate goal, unlike foreign-language communicative competence, is to ensure communication in the context of cultural dialogue. It implies the ability to communicate successfully in a variety of cultural contexts through the understanding and assimilation of both one's own culture.

Analysis of recent research and publications. Recently, there have been many works of domestic scientists devoted to intercultural communication and interaction in various fields of science, in particular, various aspects of intercultural communication are of interest to philosophers (K. Apel, L. Bueva, Y. Habermas, K. Jaspers, M. Kagan, O. Potebnya and others), sociologists (T. Burmistrova, B. Erasov, Y. Harutyunyan, N. Hasanov, G. Hofsted, V. Konetska, A. Prigozhin, etc.), cultural scientists (S. Harutyunov, G. Neshchymenko, O. Taylor), linguists (G. Filipchuk, 
A. Furman), psychologists (B. Ananiev, O. Bodalev, M. Byram, E. Falkova, N. Formanovskaya, V. Kostomarov, K. Kramsch, V. Myasishchev, G. Neuner G. Pochepzo, Y. Smirnov, B. Safonova, S. Ter-Minasova, E. Vereshchagin), who argue that the barrier between the representatives of different countries is insufficient to overcome the cultural barrier. The problem of the study of intercultural communication and its components is theoretically substantiated in the works of N. Borysko, I. Golub, O. Kvasova, Y. Kuzmenko, D. Lussier, M. Pisanko, V. Safonova, G. Zarate and others.

Setting an objective. The objective of the article is to determine the term intercultural interaction and analyze different classifications and typologies of researches of intercultural interaction and using it in education.

Presentation of basic material. "Intercultural interaction" refers to the behavior (including, but not limited to, verbal and nonverbal communication) that occurs when members of different cultural groups engage in joint activity. Such a definition raises a number of questions, including how to distinguish different cultural groups and what interaction entails. Traditionally nationality or ethnicity has been taken as the criterion for distinguishing cultural groups, but in fact the situation is much more complex than this. We are all members of multiple different cultural groups (e.g., professional, organizational, religious), each of which can be said to have its own culture in terms of values, norms, and patterns of behavior [7].

In modern science there are different ways of typology of interaction and there are different points of view. Researchers in intercultural interactions differentiate and classify them. One of the simplest typologies is based on a direct analogy with the interaction of cultural groups.

The main criterion that determines intercultural interaction is the result the impact of one culture on another. According to this indicator, interaction between two cultures is done in one of four scenarios [4, p. 130-136]:

1) "plus on plus" - mu tual assistance to development;

2) "plus for minus" - assimilation (absorption) of one culture by another;

3) "minus plus" - a model of interaction similar to the second variant, only counterparties change places;

4) "minus for minus" - both interacting cultures have a negative impact one on one.

The more detailed theoretical aspect of the typology of intercultural interaction was proposed by V. Branskii. Within the limits of the theory of social ideal, he identifies four basic principles of interaction between competing media ideals [1, p. 54]:

1) fundamentalism (irreconcilability);

2) compromise;

3) arbitration (neutralization);

4) convergence (synthesis).

Another well-known typology of intercultural interactions belongs to the American anthropologist F. Bock [3, p. 74], who identifies five main models of optimization of intercultural interaction that are relevant different ways of overcoming cultural shock:

1) ghettoization (avoiding any collision with another's culture through creation and support of our own closed cultural environment);

2) assimilation (abandonment of one's culture and desire to fully absorb the experience of a foreign culture necessary for life);

3) cultural exchange and interaction (an intermediate way that involves good politeness and openness on both sides);

4) partial assimilation (applying the experience of another culture in one of the spheres of life, provided they remain true to the traditions of their culture other areas);

5) colonization (actively imposing on one's own culture of one's own values, norms and models of behavior).

F. Bock's typology is characterized by greater detail and, given the anthropological orientation of his work, somewhat less visual, compared to the previous two. It also made 
meaningful decipher types of interaction. However, in this typology, in our view, it is on the social content of the interaction. In addition, models of interaction between cultures here, they are distinguished on the basis of not so much analytical but as descriptive criterion, which causes a certain shift of accents. Yes, regarding the specified research situation, the difference between "assimilation" and "colonization" one culture to another is irrelevant and some other possible ways of interaction (for example, convergence as an equal synthesis of source cultures) does not taken into account in general [3].

In modern sociology and anthropology, other attempts are made typology intercultural interactions. N. Ikonnikova, based on development of Western researchers, offers a complicated version of typology, based on a linear scheme of the progressive development of mutual perception counterparty cultures $[2$, p. 26-34):

1) ignoring differences between cultures;

2) protection of one's own cultural excellence;

3) minimizing differences;

4) accepting the presence of cross-cultural differences;

5) adaptation to another culture;

6) integration into both native and other cultures.

The main role in intercultural dialogue is played by civilizational consciousness and civilizational (basic) values. Unlike the values of ethnic or national cultures, the values of civilization always claim to be universal, addressing the fundamental contradictions of human and social being, the ability to unite humanity and become the basis of world culture. Therefore, the dialogue of civilizations is always a dialogue about their worldview principles, primary characters, the ultimate sacred values around which they merge complex socio-cultural systems.

The most important term for understanding intercultural interaction is "cultural diffusion" the mutual permeability or borrowing of cultural features and complexes from one society to another - is a multi-vector process of the interaction of cultures. In the course of cultural borrowing between different cultures, which occurs selectively, not only material culture but also scientific and technological ideas, social institutions and organizations, customs and traditions, religious dogmas and practices, values and norms of life can be exchanged. Condition of cultural diffusion is the host's willingness to accept new elements. In the context of intercultural communication, the processes of cultural diffusion are determined primarily by the mutual historical development of the cultures that interact $[8$, p. 85-93].

A constructive form of intercultural communication can be considered synthesis of cultures, which is an amalgamation of culturally diverse elements: landmarks, values, norms, types of behavior in which there is a qualitatively different formation. Synthesis occurs when the sociocultural system borrows and learns from the experience of other societies in areas that are underdeveloped within it, but retains its own inherent basis, which attests to its identity, ability to maintain integrity and stability [6, p. 4].

Culture as an integral and indispensable condition of human life is most sensitive to the processes of globalization and modernization. It has more diversity than other spheres of society (politics, economics, etc.) because it is organized not on the basis of certain laws of functioning but on the principle of spiritual authority. It does not only facilitates the simultaneous coexistence of different cultural traditions, but also promotes their mutual understanding, recognition of differences, and the development of cultural traditions by different peoples contributes to the enrichment of their socio-cultural experience. That is of primary importance in educational process, because of multicultural surrounding of our Higher Education Institutions.

At the same time, globalization threatens culture with loss of diversity and uniqueness. In the process of passing on spiritual intentions from generation to generation, culture produces clear mechanisms for their protection that can be characterized as localization (aimed at preserving and maintaining the national language, traditions, history, etc.) and projecting or adapting to the needs of time and civilization. In I. Shuliakov's view, specific manifestations of such adaptation are a 
change in cultural dominance, mythologization of reality, intercultural communication, or dialogue between cultures. The essence of the latter is the constructive or destructive interaction between representatives of different cultures within a well-defined spatial-temporal continuum [8].

A study of the world of communication shows that relationships between cultures can be different: a) utilitarian attitude of one culture to another; b) rejection of one culture by another; c) interaction, enrichment, that is, the relationship of cultures with each other as equal subjects. Just the third type of relationship that is characterized by attitude culture to culture as equal, despite and difference, dissimilarity and uniqueness is defined as intercultural dialogue. For the effective educational process we should provide this type in multicultural Higher Education Institutions [9].

Communication between representatives of different cultures can be complicated by the fact that there are some differences in the use of communication across cultures. Therefore, many scholars divide cultures into individualistic and collectivist. An example of the former may be American culture. Such cultures are characterized by a cognitive style of information exchange: requirements are made for the accuracy of concepts, the logic of expression. Representatives of the same collectivist cultures, in addition to the context of the message, play a significant role in the interlocutor and communication situations, this places importance on the form message, i.e. instead of "what" "how" is emphasized [9].

M. Weber discovered one more example of intercultural interaction - the term sensotype (mentality). It expresses the general orientation of culture, the emphasis in its development due to the peculiarities of personal characteristics formed in ethno-cultural communities. The sensual image of the world specific for this or that culture is also included in this concept. The essential role in this approach is played by a certain semantic center, a reference point in understanding of the phenomena of culture and nature. M. Weber, based on his own comparative studies, identified the Western and African culture-specific sensotype. He has shown that in Africa in the process of engraving the defining role belongs to dances, rituals, the leading role is given to training of possession of internal body sensations (proprioception), ability to develop motor stereotypes. Thus, in African cultures, priority is given to the language of rhythm, careful regulation of behaviour (for example, in conversation), tonal language (accents of consonants, special clicking sounds) and general orientation towards music, rhythmic movements. In Europe, the main focus of culture is the acquisition of visual perception, mediated by written and oral language forms in the learning process. The Western Sensotype is characterized as symbolically visually communicative, and the African Sensotype is characterized as musical and choreographic [5].

The problem of culture interaction is of paramount importance for aviation, whereas in aviation, the types of cultural interaction are diverse. Pilots performing international flights, crews consisting of representatives of different cultures, dispatchers, engineers from aircraft maintenance and ground staff are in constant contact with representatives of different cultural backgrounds, all of whom must be well aware of cultural differences and be more vigilant in this respect. Aviation industry is the most obvious example of the shifting borders of cultures and countries, nationalities and ethnicities. Namely, they have to keep in constant contact with representatives of different nationalities and religions.

Conclusion. Intercultural interaction should be considered as a process of systematic formation of personality, aimed at the development of respectful attitude towards people, people of different ethnic origin with different ways of thinking, cultural values of different peoples, the ability to interact cultures with the awareness of the importance of their own culture and their own identity based on the principles of freedom and responsibility, solidarity and international understanding, tolerance and democracy.

In pedagogics, the purpose of intercultural interaction is to make society open to other cultures, to ensure the peaceful coexistence of peoples. In addition, in today's globalized world, intercultural interaction promotes European integration and helps to maintain social peace within a multicultural society. The study of culture is the process of creating a common meaning between cultural representatives. It is an experimental process that has been going on for many years and has 
deeply penetrated our thinking, feelings and actions. The teacher and the student, in dialogue with each other, can be part of a creative event by forming an integrated and cohesive understanding of how students acquire the ability to communicate clearly and effectively in a second language, taking into account the particularities of different cultures of the norm of communication.

\section{References}

1. Branskii, V. (1997). Theoretical basis of social synergetics. Sociology of Peterburg, p. 54. [in Ukrainian].

2. Ikonnikova, N. (1995). The movements of intercultural perception. Sociological research, 11. Culture of Ukraine. 2017. Edition 58, P. 26-34 [in Ukrainian].

3. Ionin, L. (2004). Sociology of culture. $4^{\text {th }}$ edition. Moscow, P.74 [in Russian].

4. Kolesin, I. (1999). Learning approaches of sociocultural processes. Sociological research, 1, P. 130-136 [in Ukrainian]. [in Russian].

5. Loktev, S. (2009). Cultural anthropology. Educational manual. Piatigorsk, P. 39-41

6. Miazova, I. (2008). Intercultural communication: content, essence and peculiarities of manifestation. Extended abstract of candidate's thesis. Kyiv, p.4 [in Ukrainian].

7. Sarah, M., Christina, G. (2017). Teaching with Heart and Soul. Innovative Practices in Language Teacher Education, P. 103-124 [in English].

8. Shuliakov, I. (2017). Intercultural interaction and its types. Culture of Ukraine. Culturology. $58^{\text {th }}$ edition. 2017, p. 85-93 [in Ukrainian].

9. Zakharchuk, N. (2008). Culture and intercultural communication problem in philosophical-sociological aspect. Visnyk. Philosophy/Pegagogics, P. 174-178 [in Ukrainian].

МАРТИНЕНКО Надія Олександрівна, аспірант, Льотна академія Національного авіаційного університету.

\section{ВИЗНАЧЕННЯ КОНЦЕПТУ МІЖКУЛЬТУРНОЇ ВЗАЕМОДІЇ ДЛЯ АВІАЦІЙНОї ОСВІТИ}

Анотація. Метою статті $є$ аналіз різних типів міжкультурної взаємодії. Проаналізовано класифікації $і$ типологї науковців щцодо різних трактувань міжкультурної взаємодії. Розкрито сутність поняття «міжкультурна взаємодія» як поведінка (включаючи, але не обмежуючись ними, вербальну та невербальну комунікаџію), щьо виникає, коли члени різних культурних груп беруть участь у спільній діяльності. Обгрунтовано терміни діалог культур, культурна дифузія та їх зв'язок із навчальним прочесом у ЗВО. Проаналізовано різні дослідження науковиів міжкультурної взаємодї з культурологічних, психологічних, антропологічних, сочіологічних та педагогічних поглядів.

Ключові слова: культура; взаємодія;міжскльтурна взаємодія; проблеми;класифікація взаємодї; міжкультурна типологія;міжкультурний діалог. 